\title{
KEPEMIMPINAN AUTENTIK KEPALA SEKOLAH DAN MOTIVASI KERJA GURU DAN PENGARUHNYA TERHADAP DISIPLIN KERJA GURU SEKOLAH MENENGAH SWASTA
}

\author{
Rio Zeni Mandraguna ${ }^{1}$, Andri Supriadi ${ }^{2}$ \\ ${ }^{1}$ SMA PGRI 1 Sindang, Jl. Nyi Resik No.RT 1, Sindang, Indramayu Regency, West Java 45222, \\ riozenimandraguna@gmail.com \\ ${ }^{2}$ Universitas Wiralodra, Jln. Ir. H. Juanda Km 3 Indramayu, andrisupriadi@unwir.ac.id
}

Citation: Mandraguna, R.Z \& Supriadi, A. (2020). Pengaruh Kepemimpinan Autentik Kepala Sekolah Dan Motivasi Kerja Guru Terhadap Disiplin Kerja Guru SMA Swasta. Edum Journal, 3(2), 147-160

\begin{abstract}
ABSTRAK
Penelitian ini bertujuan untuk mengetahui apakah kepemimpinan autentik kepala sekolah dan motivasi kerja guru berpengaruh terhadap disiplin kerja guru di SMA Swasta Se-kabupaten Indramayu. Desain penelitian ini dirancang dengan menggunakan pendekatan penelitian survey. Sedangkan untuk tingkat eksplanasinya, penelitian ini termasuk jenis penelitian asosiatif. Dalam penelitian ini yang menjadi populasi adalah seluruh guru pada 30 SMA Swasta di Kabupaten Indramayu berjumlah 312 guru. Selanjutnya dengan menggunakan rumus tertentu diperoleh jumlah sampel sebanyak 76 orang. Teknik pengumpulan data menggunakan studi literature, angket, pengamatan dan wawancara. Sedangkan analisis data menggunakan statistik inferensial yang digunakan untuk menguji hipotesis penelitian adalah analisis korelasi dan regresi linier sederhana serta korelasi dan regresi ganda.Hasil penelitian menyimpukan bahwa (1) terdapat pengaruh yang signifikan antara kepemimpinan autentik kepala sekolah terhadap disiplin kerja guru SMA Swasta se Kabupaten Indramayu sebesar 44,5\%. (2) Terdapat pengaruh yang signifikan antara motivasi kerja guru terhadap disiplin kerja guru SMA Swasta se Kabupaten Indramayu sebesar 38,5\%,. (3) Terdapat pengaruh yang signifikan antara kepemimpinan autentik kepala sekolah dan motivasi kerja guru secara bersama-sama terhadap disiplin kerja guru SMA Swasta se Kabupaten Indramayu sebesar 51,1\%. Rekomendasi penelitian ini yakni hendaknya kepala sekolah dapat lebih menjaga kelancaran komunikasi, mempererat hubungan antar guru, serta bersikap lebih adil dan terbuka dalam penanganan konflik yang sedang terjadi, sehingga guru lebih taat pada peraturan kerja yang telah disepakati.
\end{abstract}

Kata Kunci: Kepemimpinan Autentik Kepala Sekolah, Motivasi Kerja Guru, Disiplin Kerja Guru

\begin{abstract}
This study aims to determine whether the principal's authentic leadership and teacher work motivation affect teacher work discipline in private high schools throughout the Indramayu district. The research design was designed using a survey research approach. As for the level of explanation, this research is an associative type of research. In this study, the population is all teachers at 30 private high schools in Indramayu Regency totaling 312 teachers. Furthermore, using a certain formula, the total sample size was 76 people. Data collection techniques using literature studies, questionnaires, observations, and interviews. While data analysis using inferential statistics used to test the research hypothesis is correlation analysis and simple linear regression and correlation and multiple regression. The results of the study conclude that (1) there is a significant influence between the authentic leadership of principals on the work discipline of private high school teachers throughout the Indramayu Regency amounted to $44.5 \%$. (2) There is a significant influence between teacher work motivations on the work discipline of private high school teachers in the Indramayu Regency at $38.5 \%$. (3) There is a significant influence between the authentic leadership of the principal and the work motivation of the teachers together on the work discipline of private high school teachers in Indramayu Regency by $51.1 \%$. The recommendation of this study is that the principal can better maintain smooth communication, strengthen relationships between teachers, and be more fair and open in handling conflicts that occur, so that teachers are more obedient to the agreed work regulations.
\end{abstract}

Keywords: Principal Authentic Leadership, Teacher Work Motivation, Teacher Work Discipline 


\section{PENDAHULUAN}

Guru merupakan salah satu SDM yang berada di sekolah. Suparlan (2008:12) mengatakan bahwa guru dapat diartikan sebagai orang yang tugasnya terkait dengan upaya mencerdaskan kehidupan bangsa dalam semua aspeknya, baik spiritual dan emosional, intelektual, fisikal, maupun aspek lainnya. Sedangkan menyatakan bahwa "tugas guru sebagai profesi meliputi mendidik, mengajar, dan melatih (Usman, 2000:7). Mendidik berarti meneruskan dan mengembangkan nilai-nilai hidup (Sumiati, 2018). Mengajar berarti meneruskan dan mengembangkan ilmu pengetahuan dan teknologi (Nurhaidah \& Musa, 2016). Sedangkan melatih berarti mengembangkan keterampilanketerampilan pada siswa. Mencermati uraian di atas, terlihat besarnya peran guru dalam membantu pertumbuhan dan perkembangan peserta didik (Sumiati, 2018).

Guru memiliki peran dan fungsi yang sangat penting dalam membentuk kepribadian, akhlak, mentalitas, dan moral anak (Jannah, 2019). Dengan demikian dapat dikatakan tercapainya tujuan pendidikan di sekolah sangat dipengaruhi oleh sikap guru dalam melaksanakan tugas profesinya. Mulyasa (2004:90) menambahkan professionalisme tenaga kependidikan memiliki efektivitas pendidikan yang tinggi." Kenyataan inilah yang mengharuskan guru memiliki disiplin yang tinggi dalam melaksanakan tugas dan fungsinya, karena guru adalah tokoh yang menjadi panutan bagi peserta didik dan lingkungannya (Bariroh, 2015).

$$
\text { Menurut Rahayu }
$$

menjelaskan bahwa indikator penting dari kualitas adalah disiplin. Keberadaan disiplin menjadi sangat penting karena memacu pelaksanaan program secara efektf dan menjamin dipatuhinya aturan yang telah ditetapkan. Siswanto (2003:97) menambahkan bahwa kedisiplinan guru mutlak diperlukan agar seluruh aktivitas yang sedang dan akan dilaksanakan berjalan sesuai mekanisme yang telah ditentukan.

Tersaji realita yang mengecewakan karena sepanjang 2013 banyak media, diantaranya koran O, Kompas, Jawa Pos, dan Media Online memaparkan betapa rendahnya tingkat kedisiplinan guru yang berkaitan dengan tidak dipenuhinya jam tugas. Hasil survey PGRI, penelitian kepala pembangunan SDM untuk World Bank, hasil Uji Kompetensi Guru, dan berbagai media massa sampai tahun 2013 memotret rendahnya kualitas guru. Berdasarkan data sekolah SMA PGRI 1 Sindang tahun 2013, jika dirata-ratakan dalam satu bulan 
terdapat 5\% guru yang tidak hadir tanpa keterangan. Sebanyak 10\% guru tidak mengabsen kehadiran siswa. Selain itu, sebanyak $10 \%$ guru datang terlambat ke sekolah dan sebanyak 7\% guru tidak masuk kelas pada saat jam mengajar dan $5 \%$ guru yang pulang sebelum waktunya.

$$
\text { Veithzal Rivai }
$$

menyatakan bahwa disiplin kerja guru dipengaruhi oleh berbagai faktor, baik faktor internal maupun faktor eksternal. Faktor internal yaitu faktor yang dihubungkan dengan sifat seseorang, seperti motivasi kerja, semangat kerja, dan inisiatif kerja.

Faktor eksternal, yaitu faktor-faktor yang berasal dari lingkungan seperti tingkat kesejahteraan, kepemimpinan kepala sekolah, ketegasan, pengawasan dan insentif. Dari penjelasan di atas maka dibutuhkannya peran kepemimpinan kepala sekolah dan motivasi dari dalam diri guru agar guru memiliki kesadaran untuk menerapkan disiplin kerja. Menurut Mulyasa (2004:89) Kepala sekolah professional akan memberikan dampak positif dan perubahan yang cukup mendasar dalam pembaharuan sistem pendidikan di sekolah.

Dokmaulite Gultom menyebutkan bahwa kepemimpinan kepala sekolah mempengaruhi tinggi rendahnya disiplin kerja guru. Seorang pemimpin dituntut untuk mampu mengelola organisasi, mempengaruhi secara konstruktif orang lain dan menunjukan perilaku benar yang harus dikerjakan bersama-sama serta mempengaruhi semangat kerja dan disiplin kerja kelompok (Rini, 2006). Keterbukaan kepala sekolah dalam berbagi informasi, baik informasi pembinaan kualitas guru maupun promosi jabatan guru, akan berdampak terhadap terciptanya kepercayaan dan integritas guru.

Menurut Avolio, Walumbwa \& Weber (2009) authentic leadership merupakan pola perilaku pimpinan yang mengacu pada kapasitas psikologis yang positif dan iklim etika yang positif untuk mendorong kesadaran diri perspektif moral yang diinternalisasi, pengolahan informasi seimbang dan transparansi relasional bagian dari pemimpin dalam bekerja dan pengikut sebagai pendorong dalam pengembangan diri. Pemimpin autentik memiliki kemampuan untuk meningkatkan komitmen pengikut khususnya dalam hubungan positif antara konstruk dan kinerja (Djailani, 2015). Jadi, dalam menerapkan disiplin kerja guru, tentunya membutuhkan kepemimpinan kepala sekolah yang tepat. Kepemimpinan autentik kepala skeolah dan motivasi kerja guru merupakan bagian penting dari disiplin kerja. Keduanya merupakan hal 
yang membantu dalam menerapkan disiplin kerja guru.

Dari beberapa pernyataan di atas, mengindikasikan adanya hubungan antara kepemimpinan autentik kepala sekolah dan motivasi kerja guru terhadap disiplin kerja guru. Berdasarkan hal tersebut di atas, penulis sangat tertarik untuk mengetahui apakah kepemimpinan autentik kepala sekolah dan motivasi kerja guru berpengaruh terhadap disiplin kerja guru di SMA Swasta Se-kabupaten Indramayu. Oleh karena itu, penulis tertarik untuk meneliti tentang Pengaruh Kepemimpinan Autentik Kepala Sekolah dan Motivasi Kerja Guru terhadap Disiplin Kerja Guru di SMA Swasta Kab. Indramayu.

\section{METODE PENELITIAN}

\section{Desain Penelitian}

Penelitian ini dirancang dengan menggunakan pendekatan penelitian survey. Sedangkan untuk tingkat eksplanasinya, penelitian ini termasuk jenis penelitian asosiatif. Karena data hasil penelitian ini berupa angka-angka yang harus diolah secara statistik, maka antar variabel-variabel yang diajukan objek penelitian harus jelas pertautannya (korelasinya) sehingga dapat ditentukan pendekatan statistik yang akan digunakan sebagai pengolah data yang pada gilirannyaa merupakan hasil analisis yang dapat dipercaya (reliabilitas dan validitas). Dengan demikian mudah untuk digeneralisasikan sehingga rekomendasi yang dihasilkan dapat dijadikan rujukan.

\section{Partisipan}

Dalam penelitian ini yang menjadi populasi adalah seluruh guru pada 30 SMA Swasta di Kabupaten Indramayu berjumlah 312 guru. Selanjutnya dengan menggunakan rumus tertentu diperoleh jumlah sampel sebanyak 76 orang.

\section{Teknik pengumpulan data}

Teknik pengumpulan data adalah suatu cara yang digunakan untuk memperoleh data penelitian. Teknik yang digunakan adalah sebagai berikut:

1. 1. Studi Literatur/Dokumentasi

Studi literatur/dokumentasi dengan cara membaca dan mempelajari yang berhubungan dan sesuai dengan permasalahan yaitu mengenai kepemimpinan autentik kepala sekolah, motivasi kerja guru dan disiplin kerja guru.

2. Survey

Observasi

Peneliti mengadakan pengamatan di lokasi penelitian sekitar 10 menit. Waktunya secara acak pada hari-hari sekolah.

Kuisioner (angket)

Menurut Sugiyono dalam Suryana (2015:228) "Kuisioner yaitu teknik pengumpulan data dengan cara memberi seperangkat pertanyaan atau pernyataan 
tertulis kepada responden untu dijawabnya." Sedangkan angket dalam penelitian ini adalah angket tertutup.

\section{Analisis Data}

Analisis data dilakukan dengan menggunakan statistik deskriptif, yaitu mendeskripsikan data masing-masing variabel secara tunggal. Sedangkan statistik inferensial digunakan untuk menguji hipotesis dengan terlebih dahulu dilakukan uji persyaratan analisis, yaitu uji normalitas dan homogenitas.

Statistik deskriptif yang digunakan adalah nilai tertinggi, nilai terendah, banyak kelas, interval kelas, rata-rata, median, modus, ukuran penyebaran atau variabilitas dengan menggunakan standar deviasi dan rentang skor. Selain itu digunakan juga tabel frekuensi dan grafik histogram.

Statistik inferensial yang digunakan untuk menguji hipotesis penelitian adalah analisis korelasi dan regresi linier sederhana serta korelasi dan regresi ganda yang sebelumnya dilakukan pengujian persyaratan analisis, yaitu uji homogenitas varian variabel terikat atas masing-masing variabel bebas dan uji normalitas galat baku taksiran untuk setiap regresi sederhana. Analisis dilakukan pada taraf signifikan 0,05 .

\section{HASIL PENELITIAN DAN}

\section{PEMBAHASAN}

\section{Hasil Penelitian}

Dalam kuesioner penelitian untuk masing-masing variabel, peneliti mengajukan beberapa pertanyaan/ pernyataan kepada para responden, dimana jawaban untuk masing-masing pernyataan tersebut disediakan dalam bentuk skala likert 1-5, dengan pilihan jawaban: 1 . sangat setuju, setuju, ragu-ragu, tidak setuju, dan sangat tidak setuju, 2. Sangat sesuai, sesuai, ragu-ragu, tidak sesuai, sangat tidak sesuai, 3. Selalu, sering, kadang-kadang, jarang, tidak pernah. Dengan mengunakan program SPSS for Windows diperoleh bahwa kecenderungan umum responden terhadap variabelvariabel penelitian yaitu kepemimpinan autentik kepala sekolah $\left(\mathrm{X}_{1}\right)$, motivasi kerja guru $\left(\mathrm{X}_{2}\right)$ dan disiplin kerja guru $(\mathrm{Y})$. Berikut statistik diskriptif variabel $\mathrm{X} 1, \mathrm{X} 2$ dan Y dengan menggunakan program SPSS For Windows. 
Tabel 1. Statistik Deskriptif Variabel $X_{1}, X_{2}$ dan $Y$

\begin{tabular}{|c|c|c|c|c|}
\hline & & $\begin{array}{l}\text { Kepemimpinan } \\
\text { Kepala sekolah }\end{array}$ & $\begin{array}{c}\text { Motivasi Kerja } \\
\text { Guru }\end{array}$ & $\begin{array}{c}\text { Disiplin Kerja } \\
\text { Guru }\end{array}$ \\
\hline \multirow[t]{2}{*}{$\mathrm{N}$} & Valid & 76 & 76 & 76 \\
\hline & Missing & 0 & 0 & 0 \\
\hline \multicolumn{2}{|c|}{ Mean } & 80,33 & 72,88 & 74,75 \\
\hline \multicolumn{2}{|c|}{ Median } & 78,64 & 73,50 & 74,50 \\
\hline \multicolumn{2}{|c|}{ Std. Deviation } & 12,211 & 8,411 & 7,635 \\
\hline \multicolumn{2}{|c|}{ Variance } & 149,101 & 70,746 & 58,297 \\
\hline \multicolumn{2}{|c|}{ Minimum } & 57 & 54 & 57 \\
\hline \multicolumn{2}{|c|}{ Maximum } & 109 & 93 & 94 \\
\hline \multicolumn{2}{|c|}{ Sum } & 6105 & 5539 & 5681 \\
\hline
\end{tabular}

Angket mengenai implementasi kepemimpinan autentik kepala sekolah di sebarkan ke 76 responden dengan 30 item pertanyaan yang telah teruji validitas dan reabilitasnya. Jumlah skor implementasi kepemimpinan autentik kepala sekolah adalah 6.105 dengan rata - rata 80,33, standar deviasi sebesar 12,211, serta varians 149,101 . Sedangkan skor tertinggi dalam angket variabel ini yaitu 109 dan skor terendahnya 57. Skor ideal variabel implementasi kepemimpinan autentik kepala sekolah adalah 150. Persentase variabel implementasi kepemimpinan autentik kepala sekolah yang angka prosentasenya paling tinggi yaitu Ethical/Moral sebesar 55,44\%, dari pada self awareness, transparency dan balance processing yaitu sebesar 52,34 \%, 53,28\% dan 53, $98 \%$. Angket mengenai motivasi kerja guru di sebarkan ke 76 responden dengan 30 item pertanyaan yang telah teruji validitas dan reabilitasnya. Jumlah dengan rata - rata 72,88 standar deviasi sebesar 8,411, serta varians 70,746. Sedangkan skor tertinggi dalam angket variabel ini yaitu 93 dan skor terendahnya 54. Skor ideal variable Motivasi Kerja Guru adalah 150. Persentase variable motivasi kerja guru yang angka prosentasenya paling tinggi yaitu ekstrinsik sebesar 49,37\%, dari pada ekstrinsik yaitu $47,87 \%$.

Angket mengenai disiplin kerja guru di sebarkan ke 76 responden dengan 30 item pertanyaan yang telah teruji validitas dan reabilitasnya. Jumlah skor disiplin kerja guru adalah 5681 dengan rata - rata 74,75 standar deviasi sebesar 7,635, serta varians 58,297. Sedangkan skor tertinggi dalam angket variabel ini yaitu 94 dan skor terendahnya 57. Skor ideal variable Motivasi Kerja Guru adalah 150. Persentase variabel Motivasi Kerja Guru disiplin kerja guru yang angka prosentasenya paling tinggi yaitu Ketaatan 
pada Standar Kerja sebesar 51,2\%, dari Pengujian normalitas data dalam pada frekuensi kehadiran, tingkat kewaspadaan, ketaatan pada peraturan kerja dan etika kerja yaitu sebesar 50,24 $\%, 50,44 \%, 47,48 \%$ dan 49,36. penelitian ini menggunakan bantuan sofwer SPSS23 yaitu dengan menggunakan uji Kolmogorov Smirnov test. Hasil uji Kolmogorov Smirnov test disajikan pada tabel 2. berikut:

Tabel 2. One-Sample Kolmogorov-Smirnov Test

\begin{tabular}{|c|c|c|c|c|}
\hline & & $\begin{array}{l}\text { Kepemimpinan Kepala } \\
\text { sekolah }\end{array}$ & $\begin{array}{c}\text { Motivasi Kerja } \\
\text { Guru }\end{array}$ & $\begin{array}{l}\text { Disiplin Kerja } \\
\text { Guru }\end{array}$ \\
\hline $\mathrm{N}$ & & 76 & 76 & 76 \\
\hline \multirow{2}{*}{$\begin{array}{l}\text { Normal } \\
\text { Parameters }\end{array}$} & Mean & 80,33 & 72,88 & 74,75 \\
\hline & Std. Deviation & 12,211 & 8,411 & 7,635 \\
\hline \multirow{3}{*}{$\begin{array}{l}\text { Most Extreme } \\
\text { Differences }\end{array}$} & Absolute & ,081 &, 071 & ,096 \\
\hline & Positive & ,081 & ,049 & ,062 \\
\hline & Negative &,- 044 &,- 071 &,- 096 \\
\hline \multicolumn{2}{|l|}{ Test Statistic } &, 081 &, 071 & ,096 \\
\hline \multicolumn{2}{|c|}{ Asymp. Sig. (2-tailed) } & $200^{\mathrm{c}, \mathrm{d}}$ & $200^{\mathrm{c}, \mathrm{d}}$ &, $079^{\mathrm{c}}$ \\
\hline
\end{tabular}
a. Test distribution is Normal.
b. Calculated from data.
c. Lilliefors Significance Correction.
$\mathrm{d}$. This is a lower bound of the true significance.

Dari tabel 2 terlihat bahwa hasil pengujian normalitas menggunakan Kolmogorov-Smirnov Test nilai Asymp. Sig.(2-tailed) untuk implementasi kepemimpinan autentik kepala sekolah atau $X_{1}$ sebesar 0,200, nilai Asymp. Sig.(2-tailed) untuk motivasi kerja guru atau X2 sebesar 0,200, dan nilai Asymp. Sig.(2-tailed) untuk disiplin kerja guru atau Y sebesar 0,079.

Semua nilai Asymp. Sig.(2-tailed) ketiga variabel tersebut lebih dari 0,05 (> $0,05)$ berarti signifikan. Sehingga hasil pengujian diatas memberikan makna bahwa sebaran skor variabel kepemimpinan autentik kepala sekolah
(X.1), motivasi kerja guru (X.2) dan disiplin kerja guru (Y) berdistribusi normal, maka analisis untuk menguji hipotesis dapat dilakukan.

Hasil uji linearitas implementasi kepemimpinan autentik kepala sekolah (X1) atas variabel disiplin kerja guru (Y) didapatkan angka signifikan sebesar 0,181 $(0,181>0,05)$ berarti linear. Sehingga data variabel implementasi kepemimpinan autentik kepala sekolah (X1) linear dengan data variabel motivasi kerja guru (Y). Secara jelas hasil tersebut dapat dilihat pada tabel 3 dibawah ini.

Tabel 3. Perhitungan Uji Linearitas Variabel X.1 Terhadap Y 
ANOVA Table

\begin{tabular}{|c|c|c|c|c|c|c|c|}
\hline & & ANO & able & & & & \\
\hline & & & $\begin{array}{c}\text { Sum of } \\
\text { Squares }\end{array}$ & $\mathrm{df}$ & $\begin{array}{l}\text { Mean } \\
\text { Square }\end{array}$ & $\mathrm{F}$ & Sig. \\
\hline Disiplin Kerja & Between & (Combined) & 4297,250 & 70 & 61,389 & 4,093 & ,059 \\
\hline Guru * & Groups & Linearity & 1944,151 & 1 & 1944,151 & 129,610 &, 000 \\
\hline Kepemimpinan & & Deviation from & 2353,099 & 69 & 34,103 & 2,274 &, 181 \\
\hline Kepala sekolah & & Linearity & & & & & \\
\hline & Within G & & 75,000 & 5 & 15,000 & & \\
\hline & Total & & 4372,250 & 75 & & & \\
\hline
\end{tabular}

Hasil uji linearitas Motivasi Kerja Guru

Sehingga data variable Motivasi Kerja $\left(\mathrm{X}_{2}\right)$ atas variabel Disiplin Kerja Guru

(Y) didapatkan angka signifikan sebesar 0,085. 0,085> 0,05 berarti linear. Guru $\left(\mathrm{X}_{2}\right)$ linear dengan data variable Disiplin Kerja Guru (Y). Secara jelas hasil tersebut dapat dilihat pada tabel 4 dibawah ini.

Tabel 4 Perhitungan Uji Linearitas Variabel X.2 Terhadap Y ANOVA Table

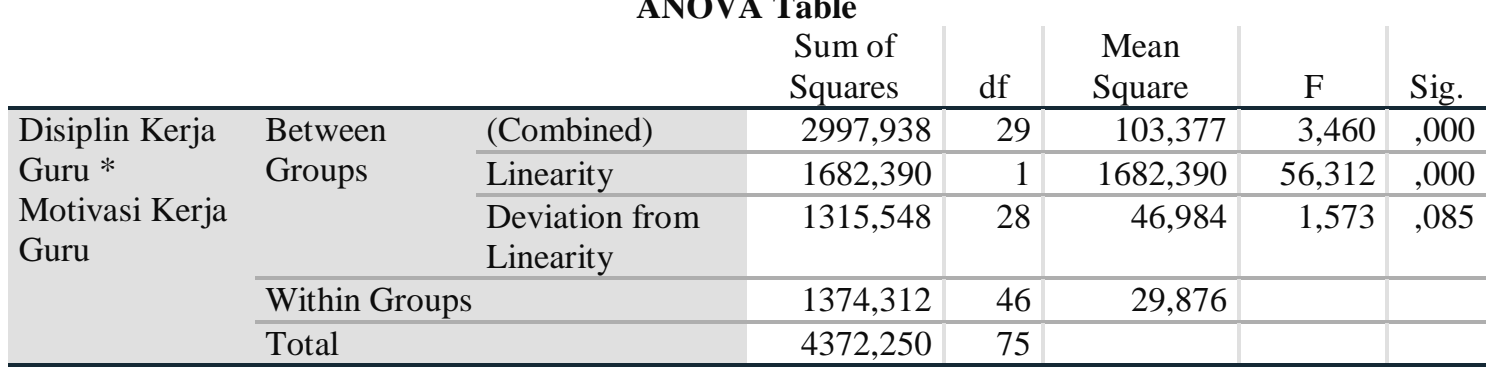

Untuk menguji hipotesis ini dilakukan dengan uji regresi linear pengaruh variabel kepemimpinan dengan menggunakan software SPSS autentik kepala sekolah $\left(\mathrm{X}_{1}\right)$ terhadap vers 23 . disiplin kerja guru (Y) dalam penelitian

Tabel 5. Koefisien Persamaan Regresi Variabel Xı terhadap Y

\begin{tabular}{|c|c|c|c|c|c|c|}
\hline \multirow[b]{2}{*}{ Model } & \multicolumn{3}{|c|}{$\begin{array}{c}\text { Unstandardized } \\
\text { Coefficients }\end{array}$} & \multirow{2}{*}{$\begin{array}{l}\text { Standardized } \\
\text { Coefficients } \\
\text { Beta } \\
\end{array}$} & \multirow[b]{2}{*}{$\mathrm{t}$} & \multirow[b]{2}{*}{ Sig. } \\
\hline & & B & Std. Error & & & \\
\hline 1 & (Constant) & 41,255 & 4,401 & & 9,374 &, 000 \\
\hline & $\begin{array}{l}\text { Kepemimpinan } \\
\text { Kepala sekolah }\end{array}$ &, 417 &, 054 & ,667 & 7,697 &, 000 \\
\hline
\end{tabular}

Persamaan regresi dari hasil perhitungan diperoleh $\hat{y}=a+b x, Y=$ $41,255+0,417$ X1. Konstanta sebesar 41,255 menyatakan bahwa jika tidak ada kenaikan nilai dari variabel kepemimpinan autentik kepala sekolah $\left(\mathrm{X}_{1}\right)$ maka disiplin kerja guru adalah 41,255. Koefisien regresi sebesar 0,667 menyatakan bahwa setiap perubahan satu skor atau nilai kepemimpinan autentik kepala sekolah memberikan kenaikan skor sebesar 0,667. 
Kemudian pengujian signifikan dilakukan dengan membandingkan antara nilai probabilitas 0,05 dengan nilai probabilitas pada nilai Sig pada tabel $4.11 \mathrm{di}$ atas nilai signifikansi sebesar 0,000 dan thitung sebesar 7,697. Karena nilai signifikan kurang dari $0,050(<0,050)$ dan nilai thitung lebih besar dari $t_{\text {tabel }}(>0,2257)$ maka Ho ditolak dan $\mathrm{H}_{1}$ diterima, artinya melalui hasil penelitian dapat membuktikan bahwa kepemimpinan autentik kepala sekolah secara partial berpengaruh terhadap disiplin kerja guru.

Berdasarkan penjelasan diatas, maka pengujian hipotesis pertama dalam penelitian ini dapat diketahui bahwa nilai Sig $(0,000<0,05)$ dan nilai thitung $7,697>$ 0,2257) maka hasilnya $\mathrm{H} 0$ ditolak dan $\mathrm{H}_{1}$ diterima, artinya terdapat pengaruh positif dan signifikan kepemimpinan autentik kepala sekolah terhadap disiplin kerja guru SMA Swasta se Kabupaten Indramayu.

Untuk menyatakan besar kecilnya pengaruh variabel $\mathrm{X}_{1}$ terhadap $\mathrm{Y}$ dengan cara menghitung besarnya koefisien determinasi dan diolah dengan software SPSS pada tabel 6 berikut :

Tabel 6. Koefisien Determinasi Variabel Xı terhadap Y Model Summary

\begin{tabular}{|c|c|c|c|c|c|c|c|c|c|}
\hline \multirow[b]{3}{*}{$\begin{array}{l}\text { Mod } \\
\text { el }\end{array}$} & \multirow[b]{3}{*}{$\mathrm{R}$} & \multicolumn{7}{|c|}{ vouer summary } & \\
\hline & & & & & \multicolumn{5}{|c|}{ Change Statistics } \\
\hline & & $\begin{array}{c}\mathrm{R} \\
\text { Square }\end{array}$ & $\begin{array}{l}\text { Adjusted R } \\
\text { Square }\end{array}$ & $\begin{array}{l}\text { Std. Error } \\
\text { of the } \\
\text { Estimate }\end{array}$ & $\begin{array}{c}\text { R } \\
\text { Square } \\
\text { Change }\end{array}$ & $\begin{array}{c}\text { F } \\
\text { Change }\end{array}$ & df1 & df2 & $\begin{array}{c}\text { Sig. F } \\
\text { Change }\end{array}$ \\
\hline 1 &, $667^{\mathrm{a}}$ &, 445 &, 437 & 5,728 &, 445 & 59,251 & 1 & 74 &, 000 \\
\hline
\end{tabular}

Dari tabel 6 diketahui bahwa $\mathrm{R}$ Square 0,445. Ini berarti koefisien determinan $=r^{2} \times 100 \%=(0,667)^{2} \mathrm{x}$ $100 \%=0,445 \times 100 \%=44,5 \%$, artinya variabel Y dipengaruhi oleh variabel $\mathrm{X}_{1}$ sebesar 44,5 \% dan sisanya sebesar $55,5 \%$ dipengaruhi oleh variabel $\mathrm{X}_{2}$ dan variabel lain yang tidak diteliti dalam penelitian ini.
Untuk menguji hipotesis pengaruh variabel Motivasi Kerja Guru $\left(\mathrm{X}_{2}\right)$ terhadap disiplin kerja guru (Y) dalam penelitian ini dilakukan dengan uji regresi linear dengan menggunakan software SPSS vers 23 diperoleh hasil seperti tabel 7 dibawah ini : 


\section{Tabel 7. Koefisien Persamaan Regresi Variabel $\mathbf{X}_{2}$ terhadap $\mathbf{Y}$}

\begin{tabular}{|c|c|c|c|c|c|c|}
\hline \multirow{2}{*}{\multicolumn{2}{|c|}{ Model }} & \multicolumn{2}{|c|}{$\begin{array}{l}\text { Unstandardized } \\
\text { Coefficients }\end{array}$} & \multirow{2}{*}{$\begin{array}{c}\text { Standardized } \\
\text { Coefficients } \\
\text { Beta } \\
\end{array}$} & \multirow[b]{2}{*}{$\mathrm{t}$} & \multirow[b]{2}{*}{ Sig. } \\
\hline & & $\mathrm{B}$ & Std. Error & & & \\
\hline \multirow[t]{2}{*}{1} & (Constant) & 33,711 & 6,072 & & 5,552 &, 000 \\
\hline & Motivasi Kerja Guru &, 563 & ,083 & ,620 & 6,803 &, 000 \\
\hline
\end{tabular}

a. Dependent Variable: Disiplin Kerja Guru

Persamaan regresi dari hasil perhitungan diperoleh $\hat{y}=33,711+0,563$ $\mathrm{X}_{2}$. Konstanta sebesar 33,711 menyatakan bahwa jika tidak ada kenaikan nilai dari variabel motivasi kerja guru $\left(\mathrm{X}_{2}\right)$, maka efektifitas (Y) adalah 33,711. Koefisien regresi 0,620 menyatakan bahwa setiap perubahan satu skor nilai motivasi kerja guru memberikan kenaikan nilai sebesar 0,620 .

Kemudian pengujian signifikan dilakukan dengan membandingkan antara nilai probabilitas 0,05 dengan nilai probabilitas pada nilai Sig. Pada tabel 4.13 diatas nilai signifikansi sebesar 0,000 dan $t_{\text {hitung }}$ sebesar 6,803. Karena nilai signifikan kurang dari $0,050(<0,050)$ dan nilai thitung lebih besar dari $t_{\text {tabel }}(>0,2257)$ maka Ho ditolak dan $\mathrm{H}_{1}$ diterima, artinya melalui hasil penelitian dapat membuktikan bahwa Motivasi Kerja Guru secara partial berpengaruh terhadap disiplin kerja guru.

Berdasarkan penjelasan diatas, maka pengujian hipotesis kedua dalam penelitian ini dapat diketahui bahwa nilai Sig $(0,000<0,050)$ maka hasilnya $\mathrm{HO}$ ditolak dan H1 diterima, artinya terdapat pengaruh positif dan signifikan Motivasi Kerja Guru terhadap Disiplin Kerja Guru SMA Swasta se Kabupaten Indramayu.

Untuk menyatakan besar kecilnya pengaruh variabel $\mathrm{X}_{2}$ terhadap $\mathrm{Y}$ dengan menghitung besarnya koefisien determinasi atau bisa dilihat dari hasil olah data dengan Software SPSS pada tabel 8 berikut:

\section{Tabel 8. Koefisien Determinasi Variabel X2 terhadap Y}

\begin{tabular}{|c|c|c|c|c|c|c|c|c|c|}
\hline \multirow[b]{2}{*}{ Model } & \multirow[b]{2}{*}{$\mathrm{R}$} & \multirow[b]{2}{*}{$\begin{array}{c}\mathrm{R} \\
\text { Square }\end{array}$} & \multirow[b]{2}{*}{$\begin{array}{l}\text { Adjusted R } \\
\text { Square }\end{array}$} & \multirow[b]{2}{*}{$\begin{array}{l}\text { Std. Error of } \\
\text { the Estimate }\end{array}$} & \multicolumn{5}{|c|}{ Change Statistics } \\
\hline & & & & & $\begin{array}{l}\text { R Square } \\
\text { Change }\end{array}$ & $\begin{array}{c}\mathrm{F} \\
\text { Change }\end{array}$ & df1 & df2 & $\begin{array}{c}\text { Sig. F } \\
\text { Change }\end{array}$ \\
\hline 1 &, $620^{\mathrm{a}}$ &, 385 & ,376 & 6,029 &, 385 & 46,284 & 1 & 74 &, 000 \\
\hline
\end{tabular}

a. Predictors: (Constant), Motivasi Kerja Guru

Dari tabel 8 diketahui bahwa $\mathrm{R} \quad 100 \%=0,385 \times 100 \%=38,5 \%$, artinya Square 0,385. Ini berarti koefisien $=\mathrm{r}^{2} \mathrm{x} \quad$ variabel $\mathrm{Y}$ dipengaruhi oleh variabel $\mathrm{X}_{2}$ 
sebesar $38,5 \%$ dan sisanya sebesar $61,5 \%$ dipengaruhi oleh variabel $\mathrm{X}_{1}$ dan variabel lain yang tidak diteliti dalam penelitian ini.

Untuk menguji Hipotesis Pengaruh Variabel Kepemimpinan autentik kepala sekolah $\left(\mathrm{X}_{1}\right)$ dan motivasi kerja guru (X2) secara bersama - sama terhadap disiplin kerja guru (Y) dalam penelitian ini dilakukan dengan uji regresi linear dengan menggunakan software SPSS vers 23 diperoleh hasil seperti tabel dibawah ini :

Tabel 9. Koefisien Persamaan Regresi Variabel $Y$ atas $X_{1}$ dan $X_{2}$ Unstandardized Coefficients

\begin{tabular}{|c|c|c|c|c|c|c|}
\hline \multicolumn{2}{|c|}{ Model } & $\mathrm{B}$ & Std. Error & Beta & $\mathrm{t}$ & Sig. \\
\hline 1 & (Constant) & 29,770 & 5,523 & & 5,390 &, 000 \\
\hline & Kepemimpinan Kepala sekolah & ,286 & ,066 & 458 & 4,349 &, 000 \\
\hline & Motivasi Kerja Guru & ,302 & ,096 & ,332 & 3,157 & ,002 \\
\hline
\end{tabular}

a. Dependent Variable: Disiplin Kerja Guru

Pada tebel 9 menunjukan persamaan regresi dari hasil perhitungan olah data dengan software SPSS yaitu: $\hat{y}$ $=29,77+0,286 X_{1}+0,302 X_{2}$. Konstanta sebesar 29,77 menyatakan bahwa jika tidak ada kenaikan nilai dari variabel kepemimpinan autentik kepala sekolah $\left(\mathrm{X}_{1}\right)$ dan motivasi kerja guru $\left(\mathrm{X}_{2}\right)$ maka disiplin kerja guru (Y) adalah 29,77.
Koefisien regresi sebesar 0,286 dan 0,302 menyatakan bahwa setiap perubahan satu skor atau nilai kepemimpinan autentik kepala sekolah dan motivasi kerja guru akan memberikan kenaikan skor 0,286 dan 0,302 unit pada disiplin kerja guru .Persamaan tersebut akan diuji secara statistik apakah signifikan atau tidak dengan hasil uji seperti pada tabel 4.16 berikut ini :

Tabel 10. Hasil Uji Signifikasi Regesi Variabel $Y$ atas $X_{1}$ dan $X_{2}$

\begin{tabular}{llr|r|r|r|r} 
Model & & Sum of Squares & Df & Mean Square & F & Sig. \\
\hline \multirow{2}{*}{1} & Regression & 2235,909 & 2 & 1117,954 & 38,201 &, $000^{\mathrm{b}}$ \\
\cline { 2 - 7 } & Residual & 2136,341 & 73 & 29,265 & & \\
\cline { 2 - 7 } & Total & 4372,250 & 75 & & & \\
\hline
\end{tabular}

a. Dependent Variable: Disiplin Kerja Guru

b. Predictors: (Constant), Motivasi Kerja Guru, Kepemimpinan Kepala sekolah

Pengujian signifikasi untuk $5 \%$ ) dan jika dibandingkan dengan $F_{\text {tabel }}$ perhitungan regresi digunakan uji $\mathrm{F}$ pada tabel 10 menunjukan bahwa $F_{\text {hitung }}$ sebesar 38,201 dengan taraf signifikasi dengan kesalahan uji $5 \%$ derajat bebas 1 (dfi) sama dengan 2 dan derajat bebas 2 (df2) sama dengan 73 sebesar 0,2257, 0,000 kurang dari taraf nyata 0,05 ( $\alpha=$ 
maka $F_{\text {hitung }}>F_{\text {tabel }}$ berarti persamaan $\hat{y}$ $=29,77+0,286 X_{1}+0,302 X_{2}$ signifikan.

Artinya terdapat pengaruh yang signifikan antara kepemimpinan autentik kepala sekolah $\left(\mathrm{X}_{1}\right)$ dan motivasi kerja guru $\left(\mathrm{X}_{2}\right)$ secara bersama - sama terhadap disiplin kerja guru (Y) SMA Swasta se Kabupaten Indramayu.

Untuk mengetahui adanya pengaruh positif dan berapa besar pengaruh kepemimpinan autentik kepala sekolah $\left(\mathrm{X}_{1}\right)$ dan motivasi kerja guru $\left(\mathrm{X}_{2}\right)$ secara bersama - sama terhadap disiplin kerja guru (Y) SMA Swasta se Kabupaten Indramayu dilakukan uji korelasi ganda dengan hasil seperti pada tabel 11 berikut ini :

\section{Tabel 11 Perhitungan Uji Regresi Ganda}

\begin{tabular}{|c|c|c|c|c|c|c|c|c|c|}
\hline \multirow[b]{3}{*}{$\begin{array}{l}\text { Mo } \\
\text { del }\end{array}$} & \multirow[b]{3}{*}{$\mathrm{R}$} & \multicolumn{7}{|c|}{ Model Summary } & \multirow[b]{3}{*}{$\begin{array}{c}\text { Sig. F } \\
\text { Change }\end{array}$} \\
\hline & & & & Std. Error & & Chang & Statis & & \\
\hline & & $\begin{array}{c}\mathrm{R} \\
\text { Square }\end{array}$ & $\begin{array}{l}\text { Adjusted } \\
\text { R Square }\end{array}$ & $\begin{array}{l}\text { of the } \\
\text { Estimate }\end{array}$ & $\begin{array}{l}\text { R Square } \\
\text { Change }\end{array}$ & $\begin{array}{c}\mathrm{F} \\
\text { Change }\end{array}$ & df1 & $\mathrm{df} 2$ & \\
\hline 1 &, $715^{\mathrm{a}}$ &, 511 &, 498 & 5,410 &, 511 & 38,201 & 2 & 73 &, 000 \\
\hline
\end{tabular}

a. Predictors: (Constant), Motivasi Kerja Guru, Kepemimpinan Kepala sekolah

Berdasarkan hasil perhitungan program SPSS di atas, besarnya hubungan regresi ganda antara variabel kepemimpinan autentik kepala sekolah $\left(\mathrm{X}_{1}\right)$ dan motivasi kerja guru $\left(\mathrm{X}_{2}\right)$ secara bersama-sama terhadap disiplin kerja guru (Y) adalah 0,715. Hal ini menunjukan adanya pengaruh yang positif antara kepemimpinan autentik kepala sekolah $\left(\mathrm{X}_{1}\right)$ dan motivasi kerja guru $\left(\mathrm{X}_{2}\right)$ secara bersama-sama terhadap disiplin kerja guru (Y) .

\section{Pembahasan}

Secara empirik hasil dalam penelitian ini menginformasikan 1). terdapat pengaruh yang signifikan kepemimpinan autentik kepala sekolah dan motivasi kerja guru terhadap disiplin kerja guru SMA Swasta se Kab. Indramayu, serta 2). besarnya pengaruh kepemimpinan autentik kepala sekolah dan motivasi kerja guru terhadap disiplin kerja guru SMA Swasta se Kab. Indramayu ditunjukan oleh hasil penelitian bahwa kepemimpinan autentik kepala sekolah yang terdiri dari indikator (a) self awareness; (b) transparency (c) ethical/moral (d) balanced processing dan motivasi kerja guru yang terdiri dari indikator (a) intrinsik; (b) ekstrinsik; membawa implikasi yang signifikan terhadap disiplin kerja guru yang meliputi indikator (a) frekuensi kehadiran; (b) tingkat kewaspadaan; (c) ketaatan pada 
standar kerja; (d) ketaatan pada peraturan kerja (e) etika kerja.

Hal ini berarti terdapat pengaruh yang nyata dan signifikan antara kepemimpinan autentik kepala sekolah dan motivasi kerja guru secara bersamasama terhadap disiplin kerja guru SMA Swasta se Kabupaten Indramayu. Hal ini dapat di lihat dari persamaan regresi $\mathrm{Y}=$ $29,77+0,286 X_{1}+0,302 X_{2}$ Sehingga setiap perubahan skor kepemimpinan autentik kepala sekolah dan motivasi kerja guru, satu satuan dapat mengubah 0,286 dan 0,302 skor disiplin kerja guru pada arah yang sama.

Dalam penelitian ini memberikan informasi antara lain 1). kepemimpinan autentik kepala sekolah dan motivasi kerja guru memberikan pengaruh yang berarti terhadap disiplin kerja guru; 2). Salah satu cara untuk meningkatkan disiplin kerja guru SMA Swasta se Kabupaten Indramayu dengan mengefektifkan kepemimpinan autentik kepala sekolah dan motivasi kerja guru, dan 3) persentase pengaruh kepemimpinan autentik kepala sekolah dan motivasi kerja guru terhadap disiplin kerja guru sebesar $51,1 \%$ sisanya dipengaruhi oleh variable-variabel lain yang tidak diteliti.

Hasibuan (2014:193) berpendapat bahwa "kedisiplinan adalah kesadaran dan kesediaan seseorang mentaati peraturan perusahaan dan norma-norma sosial yang berlaku." Hal tersebut sejalan dengan Siswanto (2005:291) yang mengatakan bahwa "faktor-faktor dari disiplin kerja itu ada 5 yaitu frekuensi kehadiran, tingkat kewaspadaan, ketaatan pada standar kerja, ketaaatan pada peraturan kerja, dan etika kerja." Sehingga berdasarkan grafik dari masing-masing dimensi disiplin kerja guru yang angka prosentase dimensinya yang paling tinggi yaitu Ketaatan pada standar kerja sebesar 51, $2 \%$ dan yang paling rendah adalah ketaatan pada peraturan kerja yaitu sebesar 47,48 \%. Sehingga disiplin kerja guru yang di lakukan oleh guru-guru SMA Swasta se Kabupaten Indramayu adalah sangat memperhatikan frekuensi kehadiran kerjanya.

\section{KESIMPULAN}

Setelah menganalisis dan membahas hasil penelitian berkaitan dengan Pengaruh Kepemimpinan Autentik Kepala Sekolah dan Motivasi Kerja Guru terhadap Disiplin Kerja Guru SMA Swasta se Kabupaten Indramayu adalah sebagai berikut: (1) Terdapat pengaruh yang signifikan antara kepemimpinan autentik kepala sekolah terhadap disiplin kerja guru SMA Swasta se Kabupaten Indramayu sebesar 44,5\%. (2) Terdapat pengaruh yang signifikan antara motivasi kerja guru terhadap disiplin kerja guru SMA Swasta se Kabupaten Indramayu 
sebesar 38,5 \%,. (3) Terdapat pengaruh yang signifikan antara kepemimpinan autentik kepala sekolah dan motivasi kerja guru secara bersama-sama terhadap disiplin kerja guru SMA Swasta se Kabupaten Indramayu sebesar 51,1\%.

\section{Rekomendasi Penelitian}

Hendaknya kepala sekolah dapat lebih menjaga kelancaran komunikasi, mempererat hubungan antar guru, serta bersikap lebih adil dan terbuka dalam penanganan konflik yang sedang terjadi, sehingga guru lebih taat pada peraturan kerja yang telah disepakati.

\section{DAFTAR PUSTAKA}

Avolio, B., Walumbwa, F.O \& Weber, T.J. (2009). Leadership: Currenttheories and future directions, Annual Review of Psychology, 60(4),421-49.

Bariroh, S. (2015). Analisis Pengaruh Kedisiplinan Kerja Guru Terhadap Prestasi Belajar Siswa Pada Sma Negeri 1 Bumiayu Kabupaten Brebes. Jurnal Kependidikan,3(2), 33-51.

Djailani, A. R. (2015). Komunikasi Kepala Sekolah Dalam Meningkatkan Kinerja Guru Pada SMA Negeri 1 Geumpang Kabupaten Pidie. Jurnal Administrasi Pendidikan: Program Pascasarjana Unsyiah, 3(4).

Gultom, D. (2013). Pengaruh kepemimpinan kepala sekolah terhadap disiplin kerja guru di SMA Negeri 1 Sei Bamban, Kabupaten Serdang Bedagai TP 2012/2013 (Doctoral dissertation, UNIMED).

Hasibuan. (2014). Manajemen Sumber Daya Manusia (Edisi Revisi). Jakarta: PT. Bumi Aksara.

Jannah, M. (2019). Peranan Guru Dalam Pembinaan Akhlak Mulia Peserta Didik (Studi Kasus Di Mis Darul Ulum, Madin Sulamul Ulum Dan TPA Az-Zahra Desa Papuyuan). AlMadrasah: Jurnal Pendidikan Madrasah Ibtidaiyah, 137-166.

Mulyasa. (2007). Menjadi Guru Profesional menciptakan Pembelajaran Kreatif dan Menyenangkan. Bandung: Remaja Rosdakarya.

Nurhaidah \& Musa, M. I. (2016). Pengembangan kompetensi guru terhadap pelaksanaan tugas dalam mewujudkan tenaga guru yang profesional. Jurnal Pesona Dasar, 2(4).

Rahayu, S. Et al. (2014). Kepemimpinan Kepala Sekolah dan Kedisiplinan Guru SMPN Kota Surakarta. Jurnal Manajemen Pendidika, .9(2), 97-107

Rini, W. A. (2006). Kepemimpinan yang membangun tim. Jurnal Ekonomi Modernisasi, 2(2), 66-75.

Siswanto, B. (2005). Manajemen Tenaga Kerja Indonesia Pendekatan Administrasi dan operasional. Jakarta: Bumi Aksara 
Sugiyono. (2007). Metode penelitian Administrasi. Bandung: Alfabeta

Sumiati, S. (2018). Peranan Guru Kelas Dalam Meningkatkan Motivasi Belajar Siswa. TARBAWI: Jurnal Pendidikan Agama Islam,3(02), 145-164. 